\title{
PENGARUH PENDAPATAN ASLI DAERAH (PAD) TERHADAP BELANJA BARANG DAN JASA PEMERINTAH KABUPATEN KERINCI
}

\author{
Heppi Syofya ${ }^{1}$; Hendra Gustomi ${ }^{2}$ \\ ${ }^{1.2}$ Sekolah Tinggi Ilmu Ekonomi Sakti Alam Kerinci \\ E-mail : heppisyofya@gmail.com \\ E-mail : hendragustomi@gmail.com \\ diterima: 18/9/2019; direvisi: 20/3/2020; diterbitkan: 26/3/2020
}

\begin{abstract}
Potential resources in an area will have meaning and benefit for economic development and prosperity if used and developed optimally, the essence of the economic development of a region aims to improve the standard of living of the community and encourage equity and expand employment opportunities and business opportunities. In the end it is expected to improve the welfare of the community. Regions that have advances in industry and have abundant natural resources tend to have much greater local income (PAD) compared to other regions and vice versa. On one hand there are regions that are very rich because they have high own source revenues (PAD) and on the other hand there are regions that are lagging behind because they have low regional own source revenues (PAD). However the further question is whether the contribution of regional revenue which is one of the sources of regional income has a significant influence in financing direct expenditure, especially for goods and services expenditure.
\end{abstract}

Keywords: Regional original income of goods and service's

\section{PENDAHULUAN}

Kemampuan menggali dan mengembangkan potensi sumber daya dalam meningkatkan perekonomian daerah menjadi tuntutan dalam pemerintahan. Peningkatan dan kreativitas terhadap potensi sumber daya daerah mempunyai dampak bagi pembangunan ekonomi serta kesejahteraan untuk kemakmuran jika dimanfaatkan dan ditumbuhkembangkan secara optimal. Hakekat pembangunan ekonomi daerah bertujuan untuk menodorong naiknya taraf hidup masyarakat, pemerataan, perluasan peluang kerja, serta usaha yang pada akhirnya bertujuan akhir untuk meningkatkan kesejahteraan seluruh masyarakat.

PAD merupakan penerimaan dari sumber ekonomi daerah dari kegiatan utama daerah dengan mengoptimalisasikan sumber daya menjadi penerimaan PAD. Pemerintah daerah mendukung dengan memberi mutu pelayanan publik yang semakin baik. PAD merupakan hasil dari pajak yang diperoleh daerah, usaha BUMD, retribusi/ cukai daerah, hasil kelola aset daerah dan sumber PAD lainnya sesuai aturan yang diberlakukan. Pada Daerah maju dan memiliki industri serta memiliki sumber daya ekonomi yang sangat memadai biasanya memiliki realisasi PAD yang besar dibandingkan daerah lain, sebaliknya ada daerah yang terbatas sumber daya ekonomi,akan memiliki realisasi PAD kecil.

Menurut Mardiasmo (2002:17) PAD berperan sangat penting sebagai salah satu penentu kinerja keuangan serta kemandirian daerah yang merupakan indikator kemandirian daerah di ukur melalui pertumbuhan PAD pada setiap tahunnya, makin tinggi kontribusi yang diberikan PAD terhadap angka Anggaran Pendapatan dan Belanja Daerah (APBD) memperlihatkan semakin rendah kebergantungan pemerintah daerah pada pemerintah pusat. Realisasi PAD 
memiliki peran yang cukup besar untuk menentukan kebijakan pemerintah daerah dalam melaksanakan pembangunan daerah. Selanjutnya menurut Prakoso dalam Puspitasari (2009:25) belanja daerah merupakan semua aliran kas keluar pemerintah daerah pada satu periode anggaran pendapatan dan belanja daerah. Alokasi belanja daerah berupa belanja langsung dan belanja tidak langsung sedangkan sumber pendapatan daerah untuk membiayai belanja daerah berasal dari dana perimbangan, PAD, dan pendapatan daerah lain-lain yang sah, oleh karena itu PAD mempunyai pengaruh secara langsung terhadap belanja daerah yang berupa belanja barang dan jasa.

Pertumbuhan realisasi PAD Di Kabupaten Kerinci dari tahun 2009 hingga 2016 mengalami fluktuasi hal ini terlihat pada nilai reaslisasi anggaran pada tahun 2010 sebesar $29,93 \%$ tahun 2011 sebesar 17,99\% tahun 2012 realisasi PAD mengalami penurunan sebesar $8,32 \%$ hal ini disebabkan karena terjadinya penurunan realisasi anggaran dari subsektor hasil pengelolaan kekayaan daerah yang sah, tahun 2013 persentase pertumbuhan PAD meningkat sebesar 11,39\% tahun 2014 persentase pertumbuhan meningkat sebesar $46,20 \%$ tahun 2015 meningkat sebesar 18,17\% tahun 2016 persentase pertumbuhan meningkat sebesar $15,81 \%$ sedangkan rata-rata persentase pertumbuhan realisasi PAD Kabupaten Kerinci dari tahun 2009 hingga tahun 2016 sebesar $18,68 \%$ hal ini menjelaskan secara realisasi PAD kabupaten Kerinci dari tahun ke tahun mengalami peningkatan dan hanya pada tahun 2012 realisasinya mengalami penurunan sebesar $8,32 \%$ namun yang menjadi pertanyaan lebih lanjut apakah kontribusi PAD merupakan salah satu sumber pendapatan daerah yang cukup berpengaruh untuk membiayai belanja langsung terhadap belanja barang dan jasa. Tujuan penelitian ini adalah untuk mengetahui pengaruh dan besarnya pengaruh PAD pemerintah Kabupaten Kerinci.

\section{TINJAUAN PUSTAKA}

Menurut Djojohadikusumo (2001:35) mendefinisikan pembangunan ekonomi upaya memperbesar pendapatan perkapita dan mendorong meningkatnya produktivitas perkapita melalui penambahan barang modal serta keahlian. Pendapat Suryana (2000:63) mengartikan pembangunan ekonomi adalah suatu upaya pengubahan untuk mencapai tujuan yang ditetapka, usaha-usaha pembangunan mengarahkan pada peningkatan taraf tingkat hidup, martabat dan keleluasaan dengan tujuan agar usaha menggapai arah yang lebih baik dimasa yang akan datang.

Menurut Saleh (2012:5) tujuan pembangunan ekonomi selain untuk meningkatkan pendapatan nasional rill juga bertujuan meningkatkan produktivitas pembangunan. Pembangunan ekonomi yang memiliki makna yang tidak sempit dimana bertujuan menaikkan nilai produksi. Banyak yang berpendapatan bahwa pembangunan ekonomi sebagai proses holistic dan multi dimensi yang melingkupi perubahan terhadap struktur, kelembagaan dan sikapa serta gaya hidup. Pertumbuhan dalam kaca pembangunan dan perekonomian menyangkut berkembangnya pengukuran dimensi tunggal terhadap naiknya produksi serta pendapatan maupun pembangunan ekonomi. Diharapkan dengan memacu dan mendorong pertumbuhan ekonomi yang diperlihatkan dengan peningkatan pendapatan nasional secara umumnya dan/ atau pendapatan perkapita khususnya.

Menurut Schumpeter dan Hicks dalam Jhingan (2002:4) terdapat perbedaan dalam terminologi 
Jurnal Ilmiah Ekonomi dan Bisnis

Vol. 17. No.1, Maret 2020 : 72-78

EISSN : $2442-9813$

ISSN : $1829-9822$

perkembangan

pertumbuhan

ekonomi

dan

ekonomi. Dimana

perkembangan ekonomi adalah

perubahan langsung dan tidak terus menerus dalam situasi stasioner yang terus dinamis dan mengubah situasi equilibrium yang ada pada periode lalu. Sedangkan pertumbuhan ekonomi merupakan perubahan terus menerus terjadi secara lamban dan mantap melalui peningkatan akumulasi finansial dan jumlah penduduk. Sedangkan pendapat Kuznet dalam Jhingan (2002:7) pertumbuhan ekonomi merupakan kenaikan jangka panjang kemampuan daerah untuk penyediaan barang ekonomi dan jasa bagi penduduk, kemampuan terus berkembang mengacu pada kemajuan zaman, teknologi dan adaptifnya lembaga ideologis yang dibutuhkan.

Pendapat Tambunan (2001:15) menerangkan bahwa pertumbuhan ekonomi adalah tambahan produk domestik bruto (PDB) yang berarti bertambahnya pendapatan secara nasional sedangkan Arsyad (2004:38) menjelaskan pertumbuhan ekonomi didefinisikan sebagai kenaikan GDP/ GNP dengan tidak melihat apakah peningkatan itu signifikan atau kecil dari peningkatan angka kelahiran penduduk dan terjadi atau tidak pergeseran struktur ekonomi.

Telaah yang diberikan Syaukani (2002:211) menyatakan kebijakan tentang otonomi daerah desentraliasi hak kelola yang terbuka dan besar kepada daerah terutama kota dan kabupaten. Otonomi daerah dijalankan dalam rangka kembalinya berdikarinya masyarakat di seluruh wilayah serta memberikan pendidikan budjeting dan politik dinamis dalam rangka perkembangan mutu berdemokrasi, peningkatan efisiensi pelayanan publik, peningkatan percepatan pembangunan di daerah dan pada akhirnya diharapkan pula terciptanya tata laksana pemerintahan yang baik (good governance). Telaah mendalam juga dikemukan Supriatna (2003:32) keuangan daerah merupakan kemampuan pemerintah daerah untuk merencanakan, mengelola, mengawasi, dan mengendalikan serta mengevaluasi berbagai alokasi dan sumber keuangan berdasarkan kewenangan dalam rangka pelaksanaan asas otonom, desentralisasi, dekosentrasi dan tugas pemerintahan di daerah dalam aspek budjeter berupa anggaran pendapatan dan belanja daerah (APBD). Dalam Peraturan Pemerintah Nomor 105 Tahun 2000 keuangan daerah merupakan semua hak dan kewajiban daerah dalam rangka penyelenggaraan pemerintah daerah yang dapat dinilai dengan nilai moneter termasuk di dalamnya semua bentuk aset yang berhubungan dengan hak serta kewajiban daerah dalam lingkup dan esensial APBD.

Berdasarkan aturan teknis dalam Permendagri nomor 21 Tahun 2011 tentang perubahan ketiga dari Permendagri Nomor 13 tahun 2006 tentang pedoman pengelolaan keuangan daerah pasal 1 ayat 6 junto PP No. 58 tahun 2005 tentang pengelolaan keuangan daerah pasal 1 ayat 5, keuangan daerah merupakan semua hak dan kewajiban daerah dalam penyelenggaraan pemerintahan daerah yang dinilai dengan aliran kas masuk termasuk segala bentuk kekayaan sehubungan dengan hak maupun kewajiban daerah bersangkutan. Keuangan daerah dalam persepsi sempit yakni hanya hal-hal yang berkaitan dengan fungsi budjeter berupa APBD. Oleh sebab itu keuangan daerah dipresentasikan berupa APBD dan 4 (empat) dimensi keuangan daerah yakni : dimensi hak dan kewajiban, tujuan perencanaan, penyelenggaraan dan layanan publik serta dimensi nilai finansial dan barang modal (investasi dan inventarisasi).

Menurut Halim (2002:18) belanja daerah merupakan turunnya manfaat 
ekonomi selama periode/ siklus akuntansi dalam bentuk berkurangnya arus kas atau bertambahnya kewajiban yang mengurangkan nilai ekuitas dana, selain yang berkaitan dengan distribusi kepada para alokasi ekiutas dana. Menurut Bastian dan Soepriyanto (2002:5) belanja daerah adalah penurunan daya guna ekonomis masa depan atau jasa potensial selama periode penatausahaan keuangan dalam bentuk arus kas keluar atau penurunan aktiva/ ekuitas neto, selain dari yang terkait dengan distribusi ke entitas ekonomi tersebut. Menurut IASC Framework dalam Halim menjelaskan belanja daerah adalah biaya atau pengeluaran daerah merupakan turunnya daya guna secara ekonomi selama periode akuntansi dalam bentuk arus keluar/ deplasi aset atau adanya kewajiban yang berakibatkan berkurangnya ekuitas dana, selain yang berkaitan dengan distribusi kepada ekuitas dana tersebut.

\section{Menurut Sukartono (2009:15)}

PAD merupakan salah satu indikator kemadirian suatu daerah. Oleh karena itu PAD mempunyai arti penting terhadap pembiayaan daerah, semakin besar realisasi arus kas masuk daerah yang bersumber dari PAD maka dapat mencerminkan bahwa daerah tersebut memiliki tingkat kemandirian tinggi. PAD mempegaruhi belanja daerah jika ada peningkatan jumlah PAD maka terjadi peningkatan pula pada jumlah belanja/ arus kas keluar daerah yang dibelanjakan. Selanjutnya menurut Mardiasmo (2002:17) PAD memainkan peran penting dalam penentuan kinerja keuangan daerah berpengaruh searah/ positif terhadap kemandirian daerah karena salah satu indikator kemandirian suatu daerah dapat diukur melalui kenaikan PAD pertahunnya. Semakin besar realiasi PAD terhadap APBD dapat menjadi indikator semakin kecil ketergantungan pemerintah daerah terhadap alokasi dana perimbangan dari
Pemerintah Pusat. PAD memiliki peran yang cukup signifikan dan mempengaruhi kebijakan pemerintah daerah dalam menentukan kemampuan daerah untuk membiayai aktivitas pemerintah dalam melaksanakan program pembangunan wilayah di daerah dalam bentuk belanja daerah atau kas keluarnya.

\section{METODE PENELITIAN}

Jenis data dalam penelitian ini adalah data sekunder yang diperoleh dari instansi pemerintah kabupaten Kerinci yang berwenang untuk mempublikasikan data keuangan berupa gambaran umum objek penelitian, realisasi PAD kabupaten Kerinci dan realisasi belanja barang serta jasa dari tahun 2009 sampai dengan tahun 2016. Alat analisis data yang digunakan dalam penelitian ini adalah :

1. Regresi linier sederhana

$$
\mathrm{Y}=\mathrm{a}+\mathrm{b}_{\mathrm{x}}+\mathrm{e}
$$

Dimana :

$\mathrm{Y}$ : Belanja barang dan jasa pemerintah

$\mathrm{X}: \mathrm{PAD}$

a : Konstanta

b : Koefisien regresi variabel $\mathrm{x}$

e : error

2. Koefisien Determinasi

$\mathrm{KD}=\mathrm{r}^{2} \times 100 \%$

Dimana :

KD : Koefisien determinasi

$\mathrm{R}$ : koefisien korelasi

3. Uji Hipotesis

$t_{\text {hitung }}=\frac{r \sqrt{n-2}}{\sqrt{1-r^{2}}}$

Dimana :

Jika $t_{\text {hitung }}<\mathrm{t}_{\text {tabel }}$ :

Maka $\mathrm{H}_{\mathrm{o}}$ diterima dan $\mathrm{H}_{\mathrm{a}}$ ditolak, artinya tidak terdapat pengaruh yang signifikan antara PAD terhadap belanja/ pengeluaran pada barang dan jasa pemerintah Kabupaten Kerinci tahun 2009-2016.

Jika $t_{\text {hitung }}>t_{\text {tabel }}$ :

Maka $\mathrm{H}_{\mathrm{o}}$ ditolak dan $\mathrm{H}_{\mathrm{a}}$ diterima, artinya diduga terdapat pengaruh yang signifikan antara PAD 
Jurnal Ilmiah Ekonomi dan Bísnis

Vol. 17. No.1, Maret 2020 : $72-78$

EISSN : $2442-9813$

ISSN : $1829-9822$

terhadap belanja/ pengeluaran pada barang dan jasa pemerintah Kabupaten Kerinci tahun 20092016.

\section{HASIL DAN PEMBAHASAN}

Perkembangan PAD Kabupaten Kerinci

Tabel 1: Perkembangan Target dan Realisasi Pendapatan Asli Daerah Kabupaten Kerinci Tahun 2009-2016

\begin{tabular}{|c|c|c|c|}
\hline Tahun & $\begin{array}{c}\text { Target PAD } \\
(\mathrm{Rp})\end{array}$ & $\begin{array}{c}\text { Realisasi PAD } \\
(\mathrm{Rp})\end{array}$ & $\begin{array}{c}\text { Persentase } \\
\text { Realisasi } \\
(\%)\end{array}$ \\
\hline 2009 & $20.806 .225 .538,39$ & $22.779 .763 .240,55$ & 109,49 \\
\hline 2010 & $22.883 .018 .741,39$ & $29.598 .713 .208,08$ & 129,35 \\
\hline 2011 & $31.537 .153 .761,39$ & $34.924 .903 .019,66$ & 110,74 \\
\hline 2012 & $33.388 .190 .930,00$ & $32.020 .001 .879,23$ & 95,90 \\
\hline 2013 & $40.783 .693 .656,00$ & $40.783 .893 .656,00$ & 100,00 \\
\hline 2014 & $55.083 .143 .319,00$ & $59.626 .711 .527,91$ & 108,25 \\
\hline 2015 & $66.598 .697 .406,32$ & $70.463 .809 .684,80$ & 105,80 \\
\hline 2016 & $70.116 .816 .200,00$ & $81.320 .041 .327,77$ & 115,98 \\
\hline Jumlah & $341.196 .939 .552,49$ & $371.517 .837 .544,00$ & 875,51 \\
\hline $\begin{array}{c}\text { Rata- } \\
\text { rata }\end{array}$ & $42.649 .617 .444,06$ & $46.439 .729 .693,00$ & 109,44 \\
\hline
\end{tabular}

Sumber: BPRD Kabupaten Kerinci Tahun 2019

Perkembangan target PAD Kabupaten Kerinci dari tahun 2009 hingga 2016 selalu meningkat, rata-rata target PAD dalam kurun waktu 8 (delapan) tahun sebesar Rp.42.649.617.444,06,begitu juga dengan realisasi PAD kabupaten Kerinci, dari tahun 2009 hingga 2011 mengalami peningkatan berkelanjutan. Pada tahun 2012 realisasi PAD terjadi penurunan, pada tahun 2013 hingga 2016 realisasi PAD mengalami peningkatan, rata-rata realisasi PAD dari tahun 2009 hingga 2016 sebesar Rp.46.439.729.693,00,- dilihat dari persentase realisasi dari tahun 2009 hingga 2016 yang terjadi fluktuasi dengan nilai rata-rata persentase realisasi terhadap target yang telah ditetapkan sebesar $109,44 \%$.

Perkembangan Target dan Realisasi Belanja Barang dan Jasa
Tabel 2: Target dan Realisasi Belanja Barang dan Jasa Kabupaten Kerinci Tahun 2009-2016

\begin{tabular}{|c|c|c|c|}
\hline Tahun & $\begin{array}{c}\text { Target Belanja } \\
\text { Barang dan Jasa (Rp) }\end{array}$ & $\begin{array}{c}\text { Realisasi Belanja } \\
\text { Barang dan Jasa } \\
(\mathrm{Rp})\end{array}$ & $\begin{array}{c}\text { Realisasi } \\
(\%)\end{array}$ \\
\hline 2009 & $76.981 .559 .025,50$ & $64.820 .654 .177,15$ & 84,20 \\
\hline 2010 & $87.926 .290 .105,00$ & $77.234 .354 .886,70$ & 87,84 \\
\hline 2011 & $110.297 .738 .938,00$ & $102.540 .075 .701,20$ & 92,97 \\
\hline 2012 & $120.332 .257 .069,00$ & $110.760 .393 .380,75$ & 92,05 \\
\hline 2013 & $142.794 .310 .070,63$ & $131.752 .206 .360,61$ & 92,27 \\
\hline 2014 & $170.887 .833 .251,60$ & $150.123 .229 .032,00$ & 87,85 \\
\hline 2015 & $193.745 .220 .543,79$ & $144.455 .054 .037,35$ & 74,56 \\
\hline 2016 & $194.349 .785 .123,32$ & $148.878 .611 .161,00$ & 76,60 \\
\hline Jumlah & $1.097 .314 .994 .126,84$ & $930.564 .578 .736,76$ & 688,33 \\
\hline $\begin{array}{c}\text { Rata- } \\
\text { rata }\end{array}$ & $137.164 .374 .265,86$ & $116.320 .572 .342,10$ & 86,04 \\
\hline
\end{tabular}

Sumber: BPKAD Kabupaten Kerinci, 2019

Rata-rata target belanja barang dan jasa naik selama 8 (delapan) tahun sebesar Rp.137.164.374.265,86,- sama dengan realisasi belanja barang dan jasa kabupaten Kerinci dari tahun 2009 hingga 2016 mengalami kenaikan. Rata-rata realisasi belanja barang dan jasa dari tahun 2009 hingga 2016 sebesar Rp 116.320.572.342,10,- yang ditelaah dari persentase realisasi dari tahun 2009 hingga 2016 mengalami fluktuasi dengan nilai ratarata persentase realisasi terhadap target yang telah ditetapkan sebesar $86,04 \%$.

Pengaruh PAD terhadap Belanja Barang dan Jasa

Tabel 3: Pengaruh PAD terhadap Belanja Barang dan Jasa di Kabupaten Kerinci Tahun 2009-2016

\begin{tabular}{|c|c|c|c|c|c|c|c|c|}
\hline \multicolumn{9}{|c|}{ Coefficients $^{a}$} \\
\hline & \multirow{2}{*}{ Model } & \multicolumn{2}{|c|}{$\begin{array}{l}\text { Unstandardized } \\
\text { Coefficients }\end{array}$} & \multirow{2}{*}{$\begin{array}{c}\begin{array}{c}\text { Standardi } \\
\text { zed } \\
\text { Coefficie } \\
\text { nts }\end{array} \\
\text { Beta }\end{array}$} & \multirow{2}{*}{$\mathrm{t}$} & \multirow{2}{*}{ Sig. } & \multicolumn{2}{|c|}{$\begin{array}{l}95,0 \% \text { Confidence } \\
\text { Interval for B }\end{array}$} \\
\hline & & B & Std. Error & & & & $\begin{array}{l}\text { Lower } \\
\text { Bound }\end{array}$ & $\begin{array}{l}\text { Upper } \\
\text { Bound }\end{array}$ \\
\hline \multirow[t]{2}{*}{1} & $\begin{array}{l}\text { (Const } \\
\text { ant) }\end{array}$ & $\begin{array}{r}538058482 \\
78,589\end{array}$ & $\begin{array}{r}15789034 \\
341,757\end{array}$ & & 3,408 & ,014 & $\begin{array}{r}15171473 \\
029,611\end{array}$ & $\begin{array}{r}924402 \\
23527, \\
568\end{array}$ \\
\hline & PAD & 1,346 &, 312 & 869 & 4,309 & ,005 & 582 & 2,111 \\
\hline
\end{tabular}


$\mathrm{Y}=53 \cdot 805 \cdot 848 \cdot 278,58+1,346_{x}$

Nilai konstanta (a) adalah positif yaitu sebesar Rp.53.805.848.278,58,artinya jika PAD bernilai 0 (nol) maka belanja barang dan jasa bernilai Rp.53.805.848.278,58,- nilai koefisien PAD sebesar Rp.1,346,- artinya bahwa PAD berpengaruh positif terhadap belanja barang dan jasa di Pemerintah Kabupaten Kerinci tahun 2009-2016 jika PAD meningkat sebesar Rp.1,- maka belanja barang dan jasa akan meningkat dengan nilai Rp.1,346,-.

\section{Uji Hipotesis}

Taraf signifikansi $0,05 \%$ dan $\mathrm{df}=$ $\mathrm{n}-\mathrm{k}(8-2=6)$, diketahui bahwa nilai $t_{\text {hitung }}$ sebesar 4,309 dan nilai $t_{\text {tabel }}$ sebesar 2,44691 dengan demikian maka $t_{\text {hitung }}>$ $t_{\text {tabel }}$ atau 4,309 > 2,44691, artinya bahwa PAD berpengaruh positif dan signifikan terhadap belanja barang dan jasa di kabupaten Kerinci pada tahun 2009-2016.

Koefisien Determinasi

Tabel 4: Besarnya Pendapatan Asli Daerah Terhadap Belanja Barang Dan Jasa Di Kabupaten Kerinci Tahun 2009-2016

\begin{tabular}{|c|c|c|r|r|c|}
\hline $\begin{array}{c}\text { Mode } \\
1\end{array}$ & $\mathrm{R}$ & $\begin{array}{c}\mathrm{R} \\
\text { Squar } \\
\mathrm{e}\end{array}$ & $\begin{array}{c}\text { Adjuste } \\
\mathrm{d} \mathrm{R} \\
\text { Square }\end{array}$ & $\begin{array}{c}\text { Std. Error of the } \\
\text { Estimate }\end{array}$ & $\begin{array}{c}\text { Durbin } \\
- \\
\text { Watso } \\
\mathrm{n}\end{array}$ \\
\hline 1 & $\begin{array}{r}, 869 \\
\mathrm{a}\end{array}$ &, 756 &, 715 & $\begin{array}{r}17626014953,654 \\
10\end{array}$ &, 608 \\
\hline
\end{tabular}

Koefisien korelasi PAD terhadap belanja barang dan jasa di Kabupaten Kerinci sebesar 0,869, maka besarnya pengaruh PAD terhadap Belanja Barang dan Jasa Pada Kabupaten Kerinci sebesar $75,60 \%$ dan sisanya sebesar $24,40 \%$ dipengaruhi oleh variabel lain yang tidak diteliti dalam penelitian ini.

\section{KESIMPULAN DAN SARAN}

PAD berpengaruh signifikan terhadap belanja barang dan jasa pemerintah kabupaten Kerinci pada tahun 2009-2016 hal ini dapat dilihat dari nilai $t_{\text {hitung }}>t_{\text {tabel }}$ dengan nilai 4,309 $>2,44691$ dan diperoleh nilai koefisien PAD sebesar 1,346, artinya bahwa jika PAD meningkat sebesar Rp.1,- maka belanja barang dan jasa pemerintah Kabupaten Kerinci akan meningkat sebesar Rp.1,346,- dan besarnya pengaruh atau kontribusi PAD terhadap belanja barang dan jasa pemerintah kabupaten Kerinci tahun 2009-2016 adalah sebesar $75,60 \%$ selebihnya sebesar $24,40 \%$ dipengaruhi oleh variabel lain yang tidak dikaji dalam penelitian ini.

Diharapkan kepada pemerintah kabupaten Kerinci pada masa yang akan datang untuk lebih meningkatkan pengelolaan sumber pendapatan daerah yang diperoleh dari PAD hal ini menunjukkan bahwa jika PAD mengalami peningkatan maka ketersediaan sumber dana pemerintah dalam melaksanakan pemerintahan dan pembangunan di kabupaten Kerinci akan lebih besar meskipun sumber keuangan dari pemerintah pusat merupakan sumber utama bagi pemerintah kabupaten Kerinci. 
Jurnal Ilmiah Ekonomi dan Bísnis

Vol. 17. No.1, Maret 2020 : 72-78

EISSN : $2442-9813$

DAFTAR PUSTAKA

Arsyad, Lincolin. 2004. Ekonomi Pembangunan. Edisi Keempat. Yogyakarta, Penerbit STIE YKPN.

Badan Pajak dan Retribusi Daerah. 2019. Kabupaten Kerinci.

Badan Pengelolaan Keuangan dan Aset Daerah.2019. Kabupaten Kerinci.

Bastian, Indra. 2007. Sistem Akuntansi Sektor Publik. Jakarta, Penerbit. Salemba Empat.

Djojohadikusumo, Sumitro. 2001. Ekonomi Pembangunan, Jakarta, Penerbit Pustaka Ekonomi.

Halim, Abdul. 2002. Akuntansi Keuangan Daerah, Jakarta, Penerbit Salemba Empat,

Jhingan, M.L. 2002. Ekonomi Pembangunan dan Perencanaan, Jakarta, Penerbit Rajawali Press.

Mardiasmo. 2002. Otonomi dan Manajemen Keuangan Daerah, Yogyakarta, Edisi kedua. Penerbit Andi Offset.

Sari, P. Noni dan Idhar Yahya. 2009. Pengaruh Dana Alokasi Umum (DAU)dan Pendaptan Asli Daerah (PAD) terhadap belanja langsung. Universitas Sumatera Utara, Medan.

Suryana, E. P. 2000. Ekonomi Pembangunan: Problematika dan Pendekatan, Jakarta, Penerbit Salemba Empat Edisi Pertama.

Syaukani, 2002. Otonomi Derah dalam Negara Kesatuan. Yogyakarta, Penerbit Pustaka Pelajar.
Supriatna, Tjahya, 2003. Strategi Pembangunan dan Kemiskinan. Jakarta, Penerbit Rineke Cipta.

Saleh, A. Muwafik. 2012. Public Service: Communication. (Terjemahan), Malang, Penerbit UMM Press.

Masdjojo, Gregorius N. and Sukartono, S. 2009, Pengaruh Pendapatan Asli Daerah dan Dana Perimbangan Terhadap Belanja Daerah Serta Analisis Flaypaper Effect Kabupaten/Kota Di Jawa Tengah Tahun 2006-2008.

Tambunan, Tulus. 2001. Perekonomian Indonesia : Teori dan Temuan Empiris. Jakarta, Penerbit Ghalia Indonesia.

Undang-Undang, R.I. No. 23 Tahun 2014 Tentang. Pemerintahan Daerah.

Undang-Undang, R.I. No. 33 Tahun 2004 Tentang. Perimbangan Keuangan antara Pemerintah Pusat dan Daerah.

Peraturan Presiden Republik Indonesia No. 4 Tahun 2015 Tentang. Pengadaan Barang/Jasa Pemerintah.

Peraturan Pemerintah No. 58 Tahun 2005 Tentang. Pengelolaan Keuangan Daerah.

Peraturan Menteri Dalam Negeri No 21 Tahun 2011 Tentang. Pedoman Pengelolaan Keuangan Daerah. 